$\emptyset$ kt metastasering som bivirkning av kreftbehandling?

Angiogenesehemmere rettet mot VEGFreaksjonsveien er brukt i kreftbehandling. Behandlingen kan føre til skrumping av tumor og forlenget overlevelse, men effekten er ikke varig. Nå har musestudier vist at medikamentene også kan resultere i økt metastasering (Cancer Cell 2009; 15: 220-31).

Forskerne fant at selv om behandlingen med angiogenesehemmere førte til at tumoren skrumpet inn, utviklet samtidig tumorcellene økt evne til invasiv vekst og spredning. Økt invasiv evne ble også sett etter fjerning av VEGF-A-genet i musene.

Effekten på aggressivitet økte med behandlingsvarigheten og var ikke reversibel. $6 \%$ av svulstene i kontrollmusene ble klassifisert som svært invasive, sammenliknet med $54 \%$ og $63 \%$ hos mus behandlet i henholdsvis én uke og fire uker.

\section{Svangerskapsmigrene og slag}

Migrene er i økende grad blitt assosiert med slag og kardiovaskulær sykdom. En nederlandsk studie har vist at ettårsprevalensen av migrene når et maksimum på $33 \%$ for kvinner mellom 35 og 39 år. Nå har amerikanske forskere sett på sammenhengen mellom migrene og kardiovaskulær sykdom under graviditet i en populasjonsbasert pasient-kontroll-studie (BMJ 2009; 338: b664).

Studien omfattet over 18 millioner graviditeter i perioden 2000-03. 34000 kvinner hadde diagnosen svangerskapsrelatert migrene. Slag og hjerteinfarkt/hjerteog karsykdom var assosiert med migrene, med en oddsratio på henholdsvis 15,1 (95\% KI 8,3-27,4) og 2,1 (1,8-2,5). Dataene sier imidlertid ikke noe om årsak og virkning, men antyder at migrene under svangerskapet kan være en markør for vaskulære sykdommer. Det trengs flere studier for å bekrefte dette.

\section{Ikke antibiotika ved akutt laryngitt}

En metaanalyse av effekten av ulike antibiotika ved akutt laryngitt hos voksne viste ingen sikker effekt på sykdomsforløpet (Cochrane Database Syst Rev 2009; nr. 2: CD004783). Totalt 206 pasienter var inkludert i metaanalysen, der man unders $ø$ kte ev. bedring av heshet med eller uten antibiotika. Ut fra lydopptak fant man ingen signifikant forskjell, men pasienter som ble behandlet med erytromycin opplevde subjektiv bedring av hesheten etter en uke og av hosten etter to uker.

\title{
Lindrende sedering i etisk og filosofisk lys
}

I sin mest radikale form innebærer

lindrende sedering til døende at

pasienten dør i bevisstl øs tilstand.

Har man dermed «drept» vedkom-

mende som person $f \varnothing r$ døden inntrer?

Dette er et av spørsmålene som en norsk filosof og en sveitsisk lege drøfter i juninummeret av Lancet Oncology (1). Vi tar for oss klinisk-etiske og filosofiske sider ved «dyp og vedvarende lindrende sedering» de siste timer og dager av livet til terminalt syke. Vi mener at denne varianten heller bør gis den tradisjonelle betegnelsen «terminal sedering», ettersom behandlingsformen markerer avslutningen, eller slutten, på pasientens liv som sosialt vesen. I dette henseende er det ved slik sedering en uklar grense mot eutanasi.

Det betyr likevel ikke at pasienten kan betraktes som «egentlig allerede død». Biologisk sett lever han, selv om han er «sosialt død». Men har man ikke dermed «tatt livet av» personen? Det kan virke opplagt, men er det ikke. Svaret avhenger av hvordan man oppfatter begrepet «person». Enkelte sentrale filosofer i Vesten anvendes i analysen av denne problemstillingen - blant andre John Locke og Immanuel Kant. Førstnevntes personbegrep tilsier at slik sedering innebærer at personen er «drept». Med utgangspunkt i Kant kan man derimot begrunne at personen er intakt helt frem til den biologiske død - selv om vedkommende i praksis mister sin autonomi når slik sedering initieres.

Vi er skeptiske til bruken av «dyp og vedvarende lindrende sedering» $\mathrm{i}$ tilfeller med psykologisk eller eksistensiell lidelse som hovedindikasjon, fordi det kan anses som en ekstrem medikalisering av døden. Dette bør neppe være en legeoppgave, og det trekkes paralleller til dødshjelp ved såkalt livstretthet.

\section{Lars Johan Materstvedt}

lars.johan.materstvedt@ntnu.no

Filosofisk institutt

Norges teknisk-naturvitenskapelige universitet

\section{Litteratur}

Materstvedt LJ, Bosshard G. Deep and continuous palliative sedation (terminal sedation): clinicalethical and philosophical aspects. Lancet Oncol 2009; 10: 622-7.

\section{Komplikasjoner ved tokolytisk behandling}

\author{
Adrenerge betaagonister eller kombi- \\ nasjon av flere tokolytika var forbun- \\ det med høy insidens av alvorlige \\ medikamentelle reaksjoner hos \\ fødekvinner.
}

Det er ikke vist at tokolytiske medikamenter gitt ved truende prematur fødsel har gunstig effekt på fosteret, men det kan utsette fødselen for at man skal få tid til å gi det best mulig behandling. Nå har forskere fra Nederland og Belgia undersøkt insidensen av alvorlige maternelle komplikasjoner etter bruk av forskjellige tokolytika i behandlingen ved truende prematur fødsel (1).

En prospektiv kohortstudie omfattet 1920 kvinner ved 28 sykehus i Belgia som ble behandlet med ulike tokolytika. $69 \%$ fikk enkeltterapi, $15 \%$ fikk sekvensiell behandling med ulike tokolytika og $16 \%$ fikk simultan kombinasjonsbehandling. Det ble observert 14 alvorlige og 14 milde hendelser som følge av behandlingen. Syklooksygenasehemmer og oksytocinantagonist var de eneste tokolytika som ikke var forbundet med alvorlige hendelser, mens adrenerge betaagonister eller kombinasjonsbehandling var forbundet med høy insidens av alvorlige reaksjoner.
- Dette er i tråd med det vi mente å vite, sier professor Britt-Ingjerd Nesheim ved Det medisinske fakultet, Universitetet i Oslo. I Veileder i obstetrikk fra 2008 anbefales oksytocinantagonist som førstevalg ved truende prematur fødsel og kalsiumkanalblokker som annetvalg. Betaagonister, som lenge var eneste brukte medikament, har mange bivirkninger.

- Ingen behandling er vist å kunne utsette fødselen i mer enn et par døgn. Hensikten er å oppnå virkning av betametason på lungemodningen og å flytte pasienten til riktig behandlingsnivå for den for tidlig fødte. En behandlingstype som ikke er undersøkt i denne studien, er sengeleie, som er vanlig brukt - på tross av fraråding i veilederen. Det er uten effekt $\mathrm{og}$ har mange bivirkninger, ikke minst psykiske, sier Nesheim.

\section{Trine B. Haugen}

trine.b.haugen@hf.hio.no

Tidsskriftet

\section{Litteratur}

. Cohen AA, Geva-Zatorsky N, Eden E et al. Adverse drug reactions to tocolytic treatment for preterm labour: prospective cohort study. BMJ 2009; 338: b744. 